\title{
INVESTIGATING THE STATE OF AMBUSH MARKETING IN FOOTBALL AND WRESTLING
}

\author{
Farshad Tojari ${ }^{1 i}$, \\ Zinat Nikaeen ${ }^{2}$, \\ Marjan Shirahmad ${ }^{3}$, \\ Kaveh Mirani ${ }^{3}$ \\ ${ }^{1}$ Professor, \\ Sport Management, Islamic Azad University, \\ Central Tehran Branch, \\ Tehran, Iran \\ ${ }^{2}$ Assistant Professor, \\ Sport Management, Islamic Azad University, \\ Central Tehran Branch, \\ Tehran, Iran \\ ${ }^{3} \mathrm{PhD}$, Student of Marketing and Media Sport, \\ Islamic Azad University, \\ Central Tehran Branch, \\ Tehran, Iran
}

\begin{abstract}
:
One of the modern ways of investing in sports and advertising is through sports. Along with financial backers, the ambush marketing phenomenon has been around for three decades. In Iran, one of the weaknesses is the lack of rules and weakness in the implementation of marketing laws. Football and wrestling are popular sports in Iran and have significant sponsors. The purpose of this study was to investigate the situation of ambush marketing in football and wrestling. The present study is of qualitative type. The statistical population includes 12 professionals: professors of sports marketing, media officials, the Football Federation, and football wrestling and financial support. Research tools are semi-structured interviews and research methods, content analysis and thematic analysis using Nvivo8 software. The research results showed that the term hidden marketing should be used instead of ambush marketing, and strict legislation and heavy financial penalties are required by lawmakers. Although major sporting events such as the Olympics and the FIFA World Cup are more common in Western countries, we can also use their methods and rules to protect the rights of sponsors and prevent ambush marketing.
\end{abstract}

i Correspondence: email shirahmadmarjan@gmail.com 
Keywords: marketing, ambush marketing, football, wrestling

\section{Introduction}

On June 16, 2006, in the Netherlands and in the town of Cote d'Ivoire, they saw a group at the 2006 FIFA World Cup in Stuttgart, Germany. The game announced a new marketing event and introduced ambush marketing to global audiences. In response to the promotional campaign, Bavaria regularly distributed its Portuguese product to fans traveling to Germany and thousands of Dutch fans, giving them Bavarian promotional clothing. FIFA officials and competition officials prevented them from attending the stadium or forced them to take off their clothes if they attended the stadium. Budweiser's efforts and FIFA's ongoing response to support Banta's sponsorship of the tournament have prevented them from being traded and advertised in the national media. But they both encouraged Bavaria for their talent and creativity, and praised FIFA's tough efforts to support its legitimate sponsor Budweiser (Burton and Chad wick, 2009). and Most importantly, it introduced an ambush marketing to the world and, at the same time, encouraged the sports marketing industry to develop talent, creativity, support and competition.

FIFA and the National Olympic Committee, in response to the ambush marketing and dubious financial growth of this method and its ability to continue in the sports industry, considered changes in their sponsors' programs to reform their rights and monopolize classification, negotiations and contracts. These changes were a service to financial sponsors at events and increased their credibility (Crompton, 2004). As a result, there was a revolution in the sale and distribution of assets and products of legal sponsors and their encouragement for continued growth and development in sports marketing at important sporting events and for sports. Creating exclusive classifications and incentive rules for brands such as credit card companies, non-alcoholic beverages, and shoe and clothing manufacturers in competitions is not only the right of sponsors for sporting events, but also for the attention, awareness and goodwill of consumers about supporters of sports (Burton, 2010). In practice, this classification led to an exponential increase in sponsorship spending from \$ 2 million in 1984 to approximately \$ 48.6 million in 2011 . Past research shows that ambush marketing, whether legal or illegal (as indirect ambush marketing), deals with the legal value of sponsorship by creating and disturbing the consumer's mind (Burton, 2012).

If the media cooperates with ambushing marketers in sporting events, the power of action and the potential of sponsors may not continue to invest in sporting events (Johnson, 2012), and companies may take advantage of ambushes. Therefore, sports organizations should report their existence to the authorities and organizers of competitions very quickly, because high-ranking sports officials are responsible for ensuring that participation in sports remains healthy. At the 2007 Olympics, China used the best strategy (the presence of the government and the authorities and strict laws) in the field of ambushing marketers and reducing it (Noufer, 2016). Accordingly (Chand wick and Burton, 2011). There are four areas for ambush marketing research: 
1) Describe and describe ambush marketing,

2) Consumer perception, especially about brand knowledge, according to ambush marketing,

3) Ethical issues and ethics in sports and marketing,

4) Legal debate.

They also proposed and researched (Seguin and Reilly, 2008) an ambush antimarketing strategy. The researcher in Iran did not find any research on ambush marketing. Due to the fact that football and wrestling matches in world and international categories are held in Iran as well and there are investors and sponsors for these two sports, so according to research done in other countries, we look at the state of ambush marketing in football and wrestling.

\section{Method}

The present study is applied in terms of purpose and in terms of present and future perspective, which has been done qualitatively-analytically. Three steps have been used to collect and analyze the data, including semi-structured interviews with experts, content analysis of past documents and research, and thematic analysis. The statistical population includes 12 people who are marketing specialists in the Wrestling and Football Federation, 2 people, Sports Network and Sports Radio, 2 people, sponsors of football and wrestling sports, 1 person, sports marketing professors, and 7 people. Theoretical saturation was the standard for estimating sample size and sampling method. The research tool was semi-structured and analyzed using Nvivo8 software.

\section{Findings}

Based on the analysis, 4 main areas related to the situation of ambush marketing in the field of wrestling and football was discovered.

\subsection{Area One: media (government and monopoly, advertising, broadcasting rights)}

In Iran, the media, especially the Islamic Republic's radio and television, are completely state-owned, and according to the country's constitution, it is never possible to have private networks. Due to budgeting, the capacity to create various sports networks on the radio and television is also limited. In addition, it can be said that today, radio and television face the challenge of fund. In view of the above, it can be stated that radio and television has a completely advertising strategy with an exclusive position. According to the Wrestling Federation, they are required to pay for broadcasting their matches on radio and television, but they do not pay this amount, and radio and television broadcasts their matches to the public. As a result, the Wrestling Federation cannot interfere in matters related to ambush marketing in radio and television and can only prevent ambush marketers who are close to environmental advertising close to the event space. But the football federation is taking away the broadcasting rights from the radio and television, which has also become a challenge for them. Because radio and television does 
not broadcast some of these competitions or broadcasts them incompletely. An interview with the Football Federation pointed out that they stopped the ambush marketers who were doing environmental advertising. But both federations said they could not intervene in radio and television propaganda because it was a government agency, and no one could fight it.

Two other interviewees who worked in the radio and television also stated that the rules of the radio and television were very strict and that no company could conduct an ambush marketing through the radio and television. In addition, everyone pointed out that the financial sponsor contract is very important. This is a financial sponsor who can enter into negotiations with both the federations and the radio and television in her contract. But in our country, this is an erosive process that companies prefer not to pay attention to ambush marketing through the media. According to Meenghan (1998), the most common method of ambush marketing is through the media, which includes financial sponsorship of the media and advertising that takes place during media events. For media officials, nothing is more valuable than expanding their relationships with sponsors to broadcast matches and preventing the entry of ambush marketing into the media (Chadwick and Burton, 2011). The Football Federation noted the high number of sports newspapers, the lack of sports events and the lack of competition in the preparation of sports reports, which makes the level of competition to be low in the media. So, they earn money through advertising, which can be a factor in the prevalence of ambush marketing.

\subsection{Area two: rules (trademark registration rights, copyright rights, ambush marketing rules, contracts, training)}

Copyright law in Iran does not have an executive guarantee (Etna). Basically, these laws are known about works of art in Iran. This law is challenging in terms of implementation, which has prevented Iran from joining the convention.

The trademark in Iran can be protected. Since 1310, Iran has been one of the countries in Asia that has raised issues related to trademark protection in its domestic laws. The registration of marks and inventions approved in 1310 and the executive regulations of this law approved in 1337 are the basis of this protection. No case was found in connection with the ambush marketing laws. Most of the interviewees pointed out that there are few legal ways to prevent ambush marketing in Iran, and in principle, not all laws in Iran have an executive guarantee. But as a way to prevent ambush marketing, the majority of interviewers suggested that it is best to do this with the help of a lawyer at the time of concluding a contract with the supported, and always think about that it is possible not concluding contracts and obligations so there be a way that they can assess all aspects of the contract.

Meanwhile, the Wrestling and Football Federations are doing their best to defend the rights of their sponsors, according to interviews. This process will lead to the development of sponsorship in Iran and encourage companies to support the country's sports. Joining the World Trade Organization may help. Also, anti-ambush marketing laws are currently being announced and implemented by the National Olympic 
Committee for major events, and in most countries only three copyright laws, spiritual right and contract laws are sufficient (McCelvey and Grady, 2008). In this case, ambushing marketing does not work illegally because the law of trademark registration includes logos and slogans. This law generally cannot prevent ambushing marketing, but ambushing marketers do not abuse the trademarks, logos, and slogans of legal sponsors (Chadwick and Burton, 2010). in five types of ambush marketing, only the first one is illegal, and the other is a violation of the rules of the National Olympic Committee and the contracts of sponsors, and this happens when ambush marketers accompany a sporting event (Dixon et al., 2015).

Most of the interviewees stated that ambush marketing methods did not comply with the rules at all, and experts said that ambushing marketing was not illegal. Most interviewees believed that ambush marketing was creative, so it was less likely to be prosecuted.

Interviewer No. 1 said that "conflict management needs to be done so that we can manage ambush marketing and financial backers together, and that the Football Federation can turn them into financial backers during negotiations with ambushing marketers".

In Iran, there are fewer international and international competitions than in other countries, so the knowledge of sports management and event management has not yet been used professionally in Iranian sports. The lack of information from individuals and companies about the legal rights of sponsors and the prevalence of copying has led some companies to unknowingly use the direct ambush strategy. According to the majority of interviewees, due to the economic recession, lack of technology, investment in production and years of sanctions, people tend to use ambush marketing and copying. According to some interviewees, people should be taught about ambush marketing and culture must be created so that people can support and use the original brand. This does not mean that people will buy expensive products, but it does mean that they will buy products under the real name of the manufacturer and that the manufacturer will try to improve the quality of their products. Lack of sponsorship and poor financial support may be the result.

\subsection{Area Three: Financial Supporters in Wrestling and Football (Low growth of financial supporters compared to the growth of sports, public sports)}

Expert 5: "One of the gaps in many activities is the lack of a sponsorship system in Iran, including in the country's sports, as well as in conferences and various social activities. And we need to look at this as a hidden demand so that we can meet that need, which is to have a sponsor. Expert 6: Sponsorship in Iranian sports does not make sense because everyone in the sponsorship debate is looking to earn money for the relevant federation or their collection. The most important principle of sponsorship in the world is that first the sponsor pays the money in full and then they do the work for her But in Iran, the process is so complicated that the team or federation that the sponsor is supposed to support has to make a lot of commitments to pay for it."

Expert 7: "If we want to look at sponsorship in Iran in particular, sponsorship in Iran has not grown in line with the growth of sports or football. The main reasons are several general issues: the growth of the country's economy, the recovery of the country's economy, the desire to produce 
and the desire to privatize. Because these were a series of weaknesses and with the conditions of the country and the issues that we had with other countries, especially with the West, these were the points that did not allow sponsorship to take place in Iran. Today, one of the pillars of sports is sponsorship."

Expert 10: "In our country, this process is challenging because sports in our country is state-owned and one of the challenges is that investing in sports is accompanied by strict rules and regulations, but in other countries no sports work is done without a sponsor and It doesn't just involve paying money."

Expert 9: "Regarding the word sponsorship, there is a point that, unfortunately, in our country, the word is not properly translated and unrecognized and it is known as financial support. While sponsorship is one of the dimensions of financial support. It also has non-financial dimensions, so I suggest the term sports support for sponsorship. Due to the fact that our sports body is generally state-owned, the real concept of sponsorship has not been implemented in the country and there is a lot of bribery and something like that. The concept of sponsorship has been introduced in our country for less than a decade and we are still at the beginning."

The majority of experts believe that sponsorship in Iran is not properly defined and this word should be defined according to the country's position. Also, sponsorship in Iran is elementary, and although we have grown in football and wrestling, but we have not been as successful in having a professional and legal sponsor in these two sports.

\subsection{Area Four: Ambush Marketing (Unethical, Illegal, Creativity, Ambush Marketing Consequences, and Ways to Prevent Ambush Marketing)}

All experts offered the same definitions of ambush marketing. Two experts said that hidden marketing or a shadow of a word is more appropriate because it is difficult for the general public to understand. All interviewees confirmed the existence and prevalence of ambush marketing in Iran, with the exception of two people, the reason being that the sponsor's presence in Iran is low and still in its infancy. Therefore, it cannot be said that there is an ambush marketing in Iran. Even when examples were presented in this regard and the opinion of the Wrestling and Football Federation was expressed, but they reiterated that such an interpretation cannot be taken. According to some experts, there are reasons for ambush marketing in Iran:

1) Iran's sport in most disciplines and clubs is public,

2) Iran's weak economy,

3) Lack of proper implementation of the law, lack of rules and erosion of the legal process,

4) Strictness and high cost in the process of accepting financial sponsors and failure to fulfill the obligations of both parties,

5) Fear of sponsorship due to moral issues of players,

6) Existence of state media and large number of newspapers,

7) Lack of competition.

All interviewees believed that if ambush marketing continued, the sponsorship process would be hampered, and sponsoring companies may not be willing to use ambush marketing or contract at lower prices. Some experts say that if ambushing 
marketing is a permanent strategy for a company, it will be unethical and will hurt the company in the long run. It can be said that no one knows about ambush marketing except experts, other people as well as sponsors are unaware of the ambush marketing.

\section{Discussion}

\subsection{Experts' views on financial sponsors in football and wrestling} Iranian sports are professional in terms of words and amateur in practice. Despite the growth of sports, there is still a lack of sponsors. Lack of proper definition of sponsor and state sports is one of the reasons for this shortage. Since Iranian sports are state-owned, companies can invest in sports that are state-owned or have a channel of communication with the government. Companies in the field of sports financial support need training to be able to continue their cooperation with sports teams for a long time. Moral issues are one of the reasons why we face a lack of financial support for athletes in Iran or the use of athletes in advertising.

\subsection{Experts' attitude regarding the definition of ambush marketing in football and wrestling}

There are many reasons for ambush marketing, the most important of which is the state of Iran's economic recession, lack of education and professional sponsorship of professional sports. Ambush marketing is creative, immoral and illegal. But according to the lack of rules, ambush marketing is not always illegal. Ambush marketing is common in football and wrestling. The reason for the prevalence of ambush marketing is the lack of investors in the private sector and strict government contracts. The Iranian people are culturally and economically inclined to use ambush marketing. Ambush marketers cannot always achieve their goals.

\subsection{The attitude of experts regarding the type of dealing with ambush marketing in football and wrestling}

Due to the lack of rules in Iran, the approach to marketing is slightly different and can be authoritative and compromising. Strict rules and heavy fines are necessary to combat ambush marketing. Yu (2013) in China, because the government organizes sporting events, can prevent the presence of ambushing marketers. But in some cases, companies are allowed to use ambush marketing because of their connections to the government.

\subsection{Legal expertise and training to combat ambush marketing in football and wrestling} Focusing on sponsors and making good use of existing rules and contracts by examining all aspects is the best way to identify and prevent ambush marketing. There are no rules for ambush marketing, only the rules of copyright, intellectual property rights and contract rules. In Iran, there is a lack of rules and weakness in law enforcement, and the process of litigation is very erosive. Copyright law exists in many countries, including the Philippines, which has the most severe penalties (depending on the degree of infringement, between 6 and 20 years in prison, as well as a fine of $\$ 5,000$ to $\$ 11,000)$. In 
Iran, copyright law It is used in artistic works and due to economic and national issues, copyright does not yet exist as a law. One of the problems in the country is the production of low-quality sports products, but Iran does not have a specific sports brand that the federations want to use Iranian clothes or shoes for their players. Using advertising, people should be encouraged to buy the original product and domestic products with the domestic brand. Like Isaco, which advertises its product, buy the original product. Yu (2013), In China, too, there are no specific rules for ambush marketing, and they use the trademark registration law to prevent ambush marketing. In China, too, enforcement is weak, and people cannot trust the law and the government. Financial sponsors in China are refusing to prosecute ambushing marketers because of the high cost and time.

\subsection{The attitude of experts regarding the consequences of ambush marketing in football and wrestling}

Marketing using sporting events not only increases the sales of products, goods or services offered during the competition, but also the positive effects that advertising and marketing have on increasing the reputation and attention of the audience in the long run. If the organizers do not take effective measures to prevent ambush marketing, the interests of official supporters will be lost. Reducing the investment of financial sponsors is one of the consequences of ambush marketing. Ambush marketing prevents financial sponsors from making maximum profit and lost their motivation to continue working with sports events.

\subsection{Experts' attitude towards ambush marketing in the media in football and wrestling} The Iranian media, especially the radio and television, is state-owned, and there is no competition in the media due to the lack of sports networks. The monopoly position and centralized management of the radio and television have made it very powerful, and they pay a small fee for the events. There is an ambush marketing on the radio and television, and the amount depends on the importance of the sporting events. The highest rate of advertising on the radio and television is one million and eighty thousand tomans per second, which in the "90" program, according to the logo engraving, subtitles, etc., reaches a maximum of eight million one hundred and forty-three thousand two hundred tomans per second. In Iran's games in the 2014 World Cup in Brazil, which was intended for three Iranian games, every 35 seconds was about 160 million tomans. Before Adel Ferdowsipour's reportage in the 2014 Games, a promotional teaser was broadcast for about fifty minutes, which according to the figures and numbers, it can be concluded that the revenue of radio and television from the three Iranian football games was about 210 billion Tomans. It is noteworthy that there is a small satellite sports network in Iran that has a worldwide live broadcast and is well known, and at the same time there are many city networks in Iran. This is an issue that can give ambush marketers a lot of opportunities.

\section{Conflict of Interest Statement}

The author declares no conflicts of interests. 


\section{About the Authors}

Professor Farshad Tojari, Islamic Azad University, Central Tehran Branch, Tehran, Iran. Research interests: sports management, sports and media, sports psychology.

Assistant Zinat Nikaeen, Islamic Azad University, Central Tehran Branch, Tehran, Iran. Research interests: organizational behavior in sports, sports management, brand and sports, sports federation studies.

Marjan Shirahmad, Islamic Azad University, Central Tehran Branch, Tehran, Iran. Research interests: sports marketing, sports development, sports media.

Kaveh Mirani, Islamic Azad University, Central Tehran Branch, Tehran, Iran. Research interests: sports marketing, sports decision making, sports media, social performance of sports managers.

\section{References}

Bruhn, M. (2010). Sponsoring: Systematishe Planung und integrative Einsatz, 5th edn, Wiesbaden: Gabler.

Burton, N. and Chadwick, S. (2010). Ambushed! New definitions for ambush marketing. The wall Street Journal/Business Insight.

Burton, N. (2012). Conceptualizing Ambush Marketing: Developing a typology of Ambush Strategy and Exploring the Managerial Implications for Sport Sponsors. Coventry University.

Chadwick, S. \& Burton, M. (2011). The evolving sophistication of ambush marketing: a typology of strategies. Thunderbird International Business Review, 53(^),709-719.

Crompton, J. L. (2004). Sponsorship Ambush Marketing in Sport. Retrieved from https://www.researchgate.net/publication/232930024 Sponsorship ambushing i n sport

Johnson, P. (2011). Chapter 1: Ambush marketing. In Ambush marketing and brand protection: Law and practice (2nd ed) (pp.3-14). Oxford University Press.

Managing Dickson, G., Naylor, M., \& Phelps, S. (2015). Consumer attitudes towards ambush marketing. Sport Management Review, 18(2), 280-290.

McKelvey, S. \& Grady, J. (2008). Sponsorship program protection strategies for special sport events: Are event organizer outmaneuvering ambush marketers? Journal of Sport Management, 22,550-558.

Meenaghan, T. (1998). Ambush marketing: Corporate strategy and consumer reaction. Psychology \& Marketing, 15(4), 305-322.

Nufer, G. (2016). Ambush marketing in sports: an attack on sponsorship or innovative marketing?. Sport, Business and Management: An International Journal.

Seguin, B. \& O`Reilly, N. (2008). The Olympic brand, ambush marketing and clutter. International Journal of Sports Marketing\& Sponsorship,4(1),62-83.

$\mathrm{Yu}, \mathrm{H}$. (2013). Blogging the Beijing Olympics: The Neoliberal Logic of Chinese Web 2.0. In Digital Media Sport (pp. 204-221). Routledge. 

be applied to their work. Under the terms of this license, no permission is required from the author(s) or publisher for members of the community to copy, distribute, transmit or adapt the article content, providing a proper, prominent and unambiguous attribution to the authors in a manner that makes clear that the materials are being reused under permission of a Creative Commons License. Views, opinions and conclusions expressed in this research article are views, opinions and conclusions of the author(s). Open Access Publishing Group and European Journal of Physical Education and Sport Science shall not be responsible or answerable for any loss, damage or liability caused in relation to/arising out of conflict of interests, copyright violations and inappropriate or inaccurate use of any kind content related or integrated on the research work. All the published works are meeting the Open Access Publishing requirements and can be freely accessed, shared, modified, distributed and used in educational, commercial and non-commercial purposes under a Creative Commons attribution 4.0 International License (CC BY 4.0). 